\title{
USE OF ICTS TO MEDIATE THE ADMINISTRATION OF KNOWLEDGE FOR DECISION-MAKING IN DEVELOPMENT PROJECTS
}

\author{
Celia Reyes-Espinoza ${ }^{1}$ and Olivia Allende-Hernández ${ }^{2^{*}}$ \\ ${ }^{1}$ Prof, University of the Mixteca, Mexico, creyes@mixteco.utm.mx \\ ${ }^{2}$ Prof. University of the Mixteca, Mexico, oallende@ mixteco.utm.mx \\ ${ }^{*}$ Corresponding Author
}

\begin{abstract}
Currently, an organization's knowledge emanating from an organization is reflected in its human capital, information technology, and business processes. Knowledge has become a potential resource in the economic and social environment. Therefore, knowledge management has a high impact on the decisionmaking of institutions. The Technological University of the Mixteca (UTM for its Spanish initials), through the Coordination for the Promotion of Development, maintains a close link between the University and the different social and economic sectors of the Mixteca Region. First making contact with rural communities and poor urban neighborhoods through the Development Promotion Brigade. As part of the functions and activities carried out by the Brigade, technical assistance and training is provided in the different productive activities in the region. These actions generate factual knowledge that including a wealth of experiences that can contribute to any instance future decisions, plans, organization, or control over the various resources necessary to carry out development projects that satisfy the needs of the communities. In this study, a strategy mediated by the use of Information and Communication Technologies (ICT) is proposed that promotes the management of organizational knowledge and the knowledge acquired in the field for the benefit of regional production and development projects. In addition, this joint work between the UTM and the Coordination for the Promotion of Development permits the creation of studies and investigation that promote community development, especially among those communities considered to be highly marginalized.
\end{abstract}

Keywords: Knowledge management, Linkage, Mixtec Region, ICT.

\section{INTRODUCTION}

In the State of Oaxaca, low wages, combined with high inequality, have contributed to one of the highest poverty rates in the country. Székely et al. (2017) published a report for the World Bank in which they establish that it is necessary to carry out actions that promote more inclusive growth, an increase in income for the population, and a reduction of inequality. In the case of Oaxaca, the conditions needed to develop its income-generating capacities do not exist. There must be investment in the development of economic activities to generate productive opportunities. Therefore, it is necessary to redirect the efforts of the state government's social initiatives towards investments in capacities and opportunities in the poorest areas. An increase in income can be achieved by generating greater participation in the economy of the most lagging sectors, the rural and indigenous language speaking populations.

The State Development Plan of Oaxaca (2016) proposed for the period 2016-2022, in the Axis "Inclusive Oaxaca with Social Development", includes the implementation of actions that promote the economic inclusion of the social and lower-income sectors of the Oaxacan population through their integration into 
productive and financial activities and initiatives of the domestic market. The strategy is to improve income through productive and financial management mechanisms for the social sector of the economy and for the lowest-income families in the state; generate capacities for linking people living in poverty through the development of capacities for their connection with opportunities in the labor market and the granting of monetary or in-kind support that contributes to the generation of their own income.

Currently, and as a consequence of the deplorable circumstances in the State of Oaxaca of extreme poverty, high rates of illiteracy, deforestation, infant mortality, migration, and insecurity (BIENESTAR, 2019), the Social Economy Enterprises (SEE) make up a formidable role for social and economic development in the State, and specifically in entities where resources are scarce and limited. Mexico has not yet managed to professionalize Social Innovation that leads to the implementation of successful inclusive business models, that is, profitability in low-income sectors can be achieved through the solidarity and collaboration of community producers who have specific needs.

The scope of study of this research is carried out at the Technological University of the Mixteca (UTM) which belongs to the System of Universities of the State of Oaxaca (SUNEO). The university is located in the municipality of Huajuapan de León in the Mixteca Region Oaxaca, which is one of the regions with the highest rate of migration, poverty, and educational underachievement (CONEVAL, 2015). UTM was created to respond to the multiple purposes of offering opportunities for scientific training, reducing the emigration of young Oaxacans, helping in the development of projects that activate the economy and generate employment, as well as opening cultural spaces that extend the benefits of knowledge to the general population (Ramírez, 1990).

The UTM promotes scientific and technological activities that involve interdisciplinary work teams in which various actors participate in the field of scientific-technological development for the benefit of the Mixtec Region, the State of Oaxaca, and the country. The university offers Development Promotion services with the aim of linking the scientific-technological activity of the university with society. Among the main functions, support is provided to rural communities, producer organizations, and private producers, technical consultancies, training courses, and the development of productive and research projects (Seara, 2020).

The University promotes the linking of networks of researchers with the productive sector, in search of the development and integration of highly marginalized communities. Faced with this perspective, development promotion activities allow for contact with the social problems of the different sectors in the region and help researchers in their possible solution. In addition, there is access to more precise information, providing the criteria and knowledge regarding the local problems, which in turn creates the conditions to discern the possible viability of productive projects. Therefore, it is necessary to develop strategies and mechanisms that allow the correct management of the knowledge generated in the university, which is considered an organization whose main asset lies in the potential of its intellectual capital.

Knowledge management means getting the most out of the experience of the organization's staff in order to assign meaning to the data, and that these in turn generate information that becomes a strategic asset for UTM and for the population in general that is interested in the sustainable development of the Mixtec Region.

The link between the UTM and regional development is of great importance due to its impact on society. This link should be promoted through the implementation of an Information System of the Mixteca Region through which the data generated by the projects and research developed by the university can be analyzed, in order to create a mechanism supported by ICT that allow the management of the knowledge generated by the productive projects implemented in the Mixtec Region.

\section{CONCEPTUAL FRAMEWORK}

Koontz \& Weihrich (1998) define the term 'Administration' as: "the process by which a variety of basic resources are obtained, deployed or used to support the objectives of the organization.". It can be indicated that the administration of knowledge must comply with this concept in which knowledge is understood as a resource. Yogesh Malhotra (2002) indicates that knowledge management embodies the organizational process that seeks the synergistic combination of data and information processing through the capabilities of ICT and the creativity and innovation capabilities of human beings.

In the present investigation, the concept that is assumed is given through the systematic process of detecting, selecting, organizing, filtering, presenting and using the information generated in the UTM, with the aim of cooperatively exploiting knowledge resources based on capital intellectual property of the professors-researchers, aimed at enhancing organizational skills and generating value, mainly for the benefit of the university community and the Mixtec Region. 


\section{KNOWLEDGE ADMINISTRATION}

Rosenberg (2002), indicates that knowledge is intangible, dynamic, committed and difficult to measure; however, without knowledge, organizational institutions cannot survive. Knowledge is presented in the tacit or explicit form (Nonaka and Takeuchi, 1995). The tacit or implicit knowledge is given in an unconscious, disjointed, personal way, a product of experience, subject to a specific context, difficult to formalize, communicate and share. Explicit knowledge can be easily described and encoded within the organization while remaining a rationally committed selection.

Organizational knowledge, when explicitly managed, is used to assist with the mission of the organization. Knowledge management is a conscious strategy of bringing the right knowledge to the right people, at the right time, and encourages people to share and put information into action in a way that improves organizational performance. The hierarchy of knowledge is based on the significant value that has been given to the data, which once processed, generates information that allows organizational learning to make strategic decisions that guarantee success. According to Rosenberg (2002), the benefits of knowledge management is to imagine it as "a corporate virtual brain", which can have the knowledge hierarchy as shown in Figure 1.

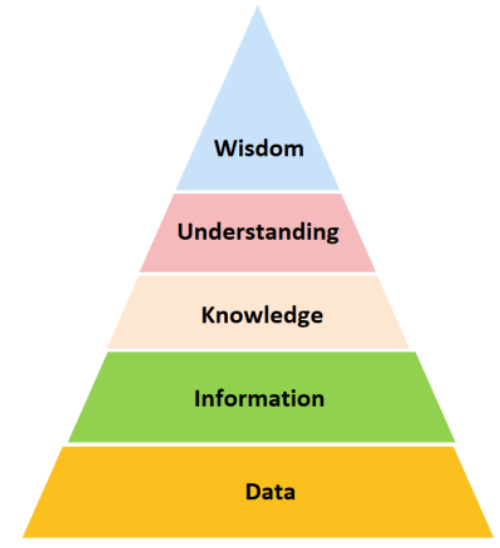

Fig. 1 Hierarchy of Knowledge. Rosenberg (2002)

As shown in the previous figure, in an organization it is necessary to learn to think in terms of a pyramid or hierarchy of knowledge, in which there are progressively higher levels of added value:

Data: A set of discrete and objective facts of an event within an organizational context. They do not have an inherent meaning; they constitute the raw material and the basis of the repository that combines the facts of the various functional areas of the organizational context.

Information: A set of data to which a specific meaning has been given in a given context.

Knowledge: Answers the question how. Generally certain members of the organization possess it and most of the time it is in their mind and not explicit. The information aims to change the way the receiver perceives "something" in such a way that it can change their perception of perception.

Understanding: The reason for things. This allows organizations continuous improvement, as long as the processes are understood and actions are taken to improve efficiency and productivity.

Wisdom: Implies the proper use of organizational learning to make strategic decisions that guarantee success. It involves the ability to go beyond available knowledge and acquire new perspectives, based on learning and experience.

The implementation of a knowledge management system forms "the virtual collective intelligence" of the members of the organization whose benefits may be greater than the cost that its maintenance may represent through ICT (Rosenberg, 2002).

\section{UTM KNOWLEDGE ADMINISTRATION}

In Figure 2, the levels of knowledge administration in the University are shown, which are integrated with the work of research and development of projects in the UTM: Document management, Creation, participation and management of information and Intelligence UTM. 


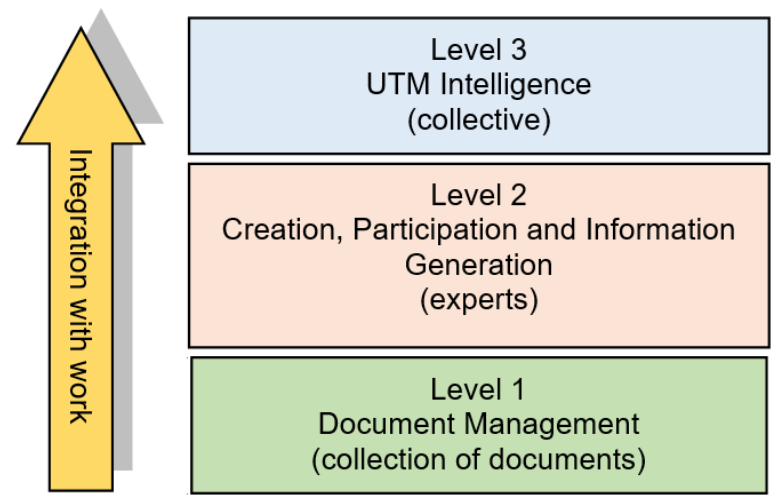

Fig. 2 Levels of UTM Knowledge Management.

Document management: One of the great efforts of knowledge management is the use of technology to access documentation. The University carries out various research projects such as field studies, theses, articles, technical reports, among others. This production has important data with which a collection of statistical and / or documentary data can be integrated. The concentration of statistical and documentary information will allow the flow of information to interested persons.

Creation: Participation and management of information. This is level at which data and / or documents are integrated creating new content and therefore increasing the knowledge database. The exploitation of the stored knowledge generates value and supports the decision-making that affects the projects of the communities of the Mixteca Region. These sources of information related to the communities of the Mixteca region would allow access to the information necessary for the implementation of development and growth strategies.

UTM Intelligence: Integration of a knowledge management system through which stored data can be accessed. The data set will support people to carry out their activities based on the information system. In addition, the resulting data must be captured and added to the system, increasing collective intelligence.

\section{CONCLUSIONS}

The UTM, through the Promotion of Development, has served 164 municipalities in the State of Oaxaca, Puebla and Morelos. In addition, it has participated in 122 productive projects promoting the development of communities. These actions aim to strengthen the productive nuclei with technological innovations that allow the adequate development of their primary activities. The purpose is to contribute to the socio-economic development of the primary productive sector of the regions, contribute significantly to the transformation of society and promote better welfare conditions (Seara, 2020).

The integration of a set of statistical and documentary information of the Mixteca Region that allows the administration of knowledge requires the support and coordination of the hierarchical organizational levels of the UTM as shown in Figure 3.
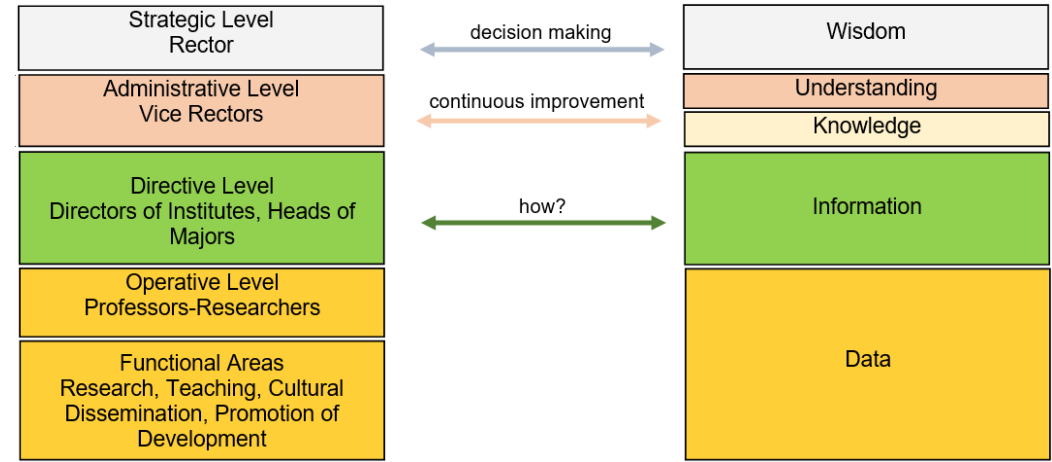

Fig. 3 Interrelation of the organizational levels of the UTM and Knowledge Management.

The implementation of UTM knowledge management implies that the strategic level of the organization has identified and valued the intellectual capital it possesses, generating in turn a strategy in terms of added value to satisfy the needs for reliable and updated information of the communities of the Mixtec Region. The 
main objective is to promote studies and research that promote the development of communities, and especially those communities considered highly marginalized.

\section{REFERENCE LIST}

Consejo Nacional de Evaluación de la Política de Desarrollo Social, CONEVAL (2015).

Koontz H. \& Weihrich H. (1998), Administración una Perspectiva Global, McGraw Hill Interamericana Editores, México.

Malhotra Y. (2002), Why Knowledge Management Systems Fail? Enablers and Constraints of Knowledge Management in Human Enterprises, Handbook on Kowledge Management 1: Knowledge Matters, Springer-Verlag, Heidelber, Germany, 577-599, 2002.

Rosenberg, Marc J. (2002), E-learning Estrategias para trasmitir conocimiento en la era digital. Construya un exitoso aprendizaje en línea en su organización. Bogotá, Colombia. Editorial McGraw-Hill.

Nonaka, I. \& Takeuchi, H. (1995), The Knowledge-Creating Company, Oxford University Press, Oxford.

Ramírez, H., (1990), Decreto de creación. Universidad Tecnológica de la Mixteca, Periódico Oficial del estado libre y soberano de Oaxaca.

Székely, M., C., Rodríguez-Castelán, I. Flores, F. Leyson and P. Mendoza (2017). La Pobreza en el Estado de Oaxaca: Evolución y Perspectivas para una Agenda de Política Social. Banco Mundial, Washington, DC.

Gobierno del Estado de Oaxaca, (2016). Plan Estatal de Desarrollo 2016-2022. https://www.finanzasoaxaca.gob.mx/pdf/planes/Plan_Estatal_de_Desarrollo_2016-2022.pdf

Seara, V. M. (2020). Hechos 2020. Sistema de Universidades Estatales de Oaxaca. http://suneo.mx/Hechos-2020-BR.pdf

Secretaría de Bienestar, (2019). ¿Sabes qué es la Economía Social?. Gobierno de México. https://www.gob.mx/bienestar/articulos/sabes-que-es-la-economia-social?idiom=es 